\title{
PENGEMBANGAN BAKAT KREATIVITAS ANAK

\section{Abstrak}

Pengembangan bakat kreativitas anak sering ditelantarkan dalam pendidikan formal, padahal amat bermakna bagi pengembangan potensi anak secara utuh dan bagi kemajuan ilmu pengetahuan serta seni budaya.

Kreativitaslah yang memungkinkan manusia meningkatkan kualitas hidupnya. Sikap dan perilaku kreatif perlu dipupuk sejak dini, agar anak didik kelak tidak hanya menjadi konsumen pengetahuan, tetapi mampu menghasilkan pengetahuan baru, tidak hanya menjadi pencari kerja, tetapi mampu menciptakan pekerjaan baru.

Dalam pengembangan kreativitas anak perlu peran sinergi dari orang tua, sekolah/guru dan masyarakat pada umumnya.

Bimbingan dan konseling perlu bagi anak berbakat kreatif. Konselor perlu menemukenali potensi anak-anak kreatif ini dan memberi sistem dukungan serta model pembelajaran yang memupuk produktivitas kreatif mereka.

Key Word: divergen, konvergen, aptitude, nonaptitude, inkubasi, iluminasi, Konfigurasi, Fragmentasi politis.

\section{PENGERTIAN BAKAT DAN KREATIVITAS}

Anak-anak yang berbakat di bidang yang sama, pengembangannya belum tentu menggunakan cara yang sama, bahkan tidak semua dapat mewujudkan bakatnya menjadi prestasi yang unggul.

*) Drs. Dirlanudin, M.Si, adalah Lektor Kepala pada Sekolah Tinggi Ilmu Administrasi (STIA) Maulana Yusuf, Serang Banten 
Menurut Utami (1999), bakat diartikan sebagai kemampuan bawaan, sebagai potensi yang masih perlu dikembangkan dan dilatih agar dapat terwujud. Sedangkan kemampuan menunjukkan suatu tindakan dapat dilakukan sekarang, sedangkan bakat memerlukan latihan dan pendidikan agar suatu tindakan dapat dilakukan di masa mendatang. Prestasi merupakan perwujudan dari bakat dan kemampuan. Prestasi yang sangat menonjol dalam salah satu bidang mencerminkan bakat yang unggul dalam bidang tersebut.

Pengembangan kreativitas sering ditelantarkan dalam pendidikan formal, padahal amat bermakna bagi pengembangan potensi anak secara utuh dan bagi kemajuan ilmu pengetahuan dan seni budaya.

Sebelum uraian lebih lanjut, terlebih dulu dikemukakan pengertian kreativitas menurut para ahli: Mclnerney and Mclnerney (1998), menyebutkan "Kreativitas adalah anak yang berupaya menghasilkan berbagai kreasi ditandai dengan sifat-sifat determinan, independen, individualistik, antusias dan menghasilkan sesuatu". Sedangkan menurut Syamsu dan A. Juntika (2005), mengemukakan bahwa kreativitas diartikan sebagai kemampuan untuk menciptakan suatu produk baru, atau kemampuan untuk memberikan gagasan baru dan menerapkannya dalam pemecahan masalah. Kreativitas meliputi ciri-ciri kognitif (aptitude): kelancaran (fluency), keluwesan (flexibility), keaslian (originality), elaborasi (elaboration) dan pemaknaan kembali (redefinition) dalam pemikiran. Sementara ciri-ciri nonkognitif (nonaptitude): motivasi, sikap, rasa ingin tahu, senang mengajukan pertanyaan dan selalu ingin mencari pengalaman baru.

Selanjutnya Utami Munandar (1999), mengemukakan kreativitas (berpikir divergen) adalah kemampuan untuk membuat kombinasi baru, berdasarkan data, informasi atau unsur-unsurnya, sehingga mampu menemukan banyak kemungkinan jawaban terhadap suatu masalah, yang tekanannya pada kuantitas, ketepatgunaan dan keragaman jawaban. 
Berdasarkan pendapat para ahli di atas dapat dikemukakan bahwa kreativitas adalah kemampuan untuk menciptakan suatu karya baru yang merupakan hasil dari pemikiran dan gagasan, termasuk kemampuan membuat alternatif pemecahan masalah berdasarkan data, informasi yang dikaji secara cerdik.

\section{KREATIVITAS PENTING DIPUPUK DAN DIKEMBANGKAN DALAM DIRI ANAK}

Kreativitas penting bagi kehidupan manusia, menurut Utami Munandar (1999), karena a) dengan berkreasi orang dapat mewujudkan dirinya dan perwujudan diri tersebut merupakan salah satu kebutuhan pokok dalam hidup manusia; b) berfikir kreatif sebagai kemampuan melihat berbagai kemungkinan penyelesaian masalah kurang mendapat perhatian dalam pendidikan formil; c) sibuk berkreatif bukan hanya menghasilkan manfaat tetapi juga memberikan kepuasan kepada individu tersebut; d) kreativitaslah yang memungkinkan manusia meningkatkan kualitas hidupnya. Sikap dan perilaku kreatif perlu dipupuk sejak dini, agar anak didik kelak tidak hanya menjadi konsumen pengetahuan, tetapi mampu menghasilkan pengetahuan baru, tidak hanya menjadi pencari kerja, tetapi mampu menciptakan pekerjaan baru.

\section{TEORI YANG MELANDASI PENGEMBANGAN KREATIVITAS}

Beberapa teori yang berusaha menjelaskan pembentukan kepribadian kreatif, di antaranya:

\section{a. Teori tentang pembentukkan pribadi kreatif.}

Diambil dari dua mazhab yaitu teori psikoanalisis dan teori humanistik untuk digunakan sebagai landasan perencanaan program pendidikan anak berbakat.

1) Teori psikoanalisis

Teori psikoanlisis melihat kreativitas sebagai hasil 
mengatasi suatu masalah, yang biasanya mulai di masa anak-anak. Pribadi kreatif dipandang sebagai seseorang yang pernah mempunyai pengalaman traumatis, sehingga manimbulkan gagasan-gagasan yang disadari dan tidak disadari bercampur menjadi pemecahan inovatif dari trauma. Tindakan kreatif mentransformasi keadaan psikhis yang tidak sehat menjadi sehat.

2) Teori Humanistik

Teori ini melihat kreativitas sebagai hasil dari kesehatan psikologis tingkat tinggi. Kreativitas dapat berkembang selama hidup, dan tidak terbatas pada lima tahun pertama.

\section{b. Teori tentang "press"}

Kreativitas anak agar dapat terwujud membutuhkan adanya dorongan dalam dirinya ( motivasi intrinsik) maupun dorongan dari lingkungan (motivasi ekstrinsik).

Dorongan internal merupakan motivasi primer untuk kreativitas ketika individu membentuk hubungan-hubungan baru dengan lingkungannya dalam upaya menjadi diri sepenuhnya (Rogers, dalam Utami, 1999). Dorongan ada pada setiap orang dan bersifat internal, ada dalam individu sendiri namun membutuhkan kondisi yang tepat untuk diekspresikan.

Kondisi lingkungan yang dapat mendorong kreativitas anak menurut pengalaman Rogers dalam psikoterapi yaitu penciptaan kondisi keamanan dan kebebasan psikologis yang memungkinkan timbulnya kreativitas yang konstruktif.

\section{c. Teori tentang proses kreatif}

Menurut teori Wallas, dalam Utami (1999) bahwa proses kreatif meliputi empat tahap:

1) Tahap persiapan yaitu memecahkan masalah dengan belajar berpikir, mencari jawaban dan bertanya pada orang lain.

2) Tahap inkubasi yaitu mencari dan mengumpulkan data/ 
informasi yang tidak dilanjutkan, seakan melepaskan diri sementara dari masalah tersebut.

3) Tahap iluminasi yaitu timbulnya inspirasi/gagasan beserta psoses psikologisnya.

4) Tahap verifikasi yaitu ide atau kreasi baru harus diuji terhadap realitas. Di sini pemikiran kreatif (divergen) harus diikuti pemikiran kritis (konvergen).

Selanjutnya teori belahan otak kanan dan kiri, berpendapat bahwa orang yang biasa menggunakan tangan kanan berarti didominasi oleh belahan otak kiri dan orang-orang yang kidal (left-handed), mereka dikuasai oleh belahan otak kanan. Dihipotesiskan bahwa belahan otak kanan terutama berkaitan dengan fungsi-fungsi kreatif.

\section{d. Teori tentang produk kreatif}

Cropley, dalam Utami (1999) mengemukakan bahwa perilaku kreatif memerlukan kombinasi antara ciri-ciri psikologis yang berinteraksi sebagai berikut: sebagai hasil berfikir konvergen manusia memiliki seperangkat unsur-unsur mental. Jika dihadapkan dengan situasi yang menuntut tindakan, individu mengerjakan dan mengembangkan unsur-unsur mental sampai timbul konfigurasi. Konfigurasi ini dapat berupa gagasan, model, tindakan, cara menyusun kata, melodi atau bentuk.

Konstruksi konfigurasi tersebut juga memerlukan motivasi, karakteristik pribadi yang sesuai, unsur-unsur sosial dan keterampilan komunikasi. Proses ini disertai perasaan dan emosi yang dapat menunjang atau menghambat.

Berdasarkan pemikiran di atas dapat dikemukakan ciri-ciri kepribadian anak yang kreatif:

a. Selalu ingin tahu dan minat yang luas;

b. Percaya diri, penuh semangat, cerdik dan tidak penurut;

c. Berani mengambil resiko, tetapi dengan perhitungan 
matang;

d. Tidak terlalu menghiraukan ejekan dari teman-temannya;

e. Berani berbeda, membuat kejutan menyimpang dari tradisi;

f. Ulet dan tekun membuat mereka tidak cepat putus asa dalam mencapai tujuannya;

g. Anak kreatif lebih terorganisasi dalam tindakan;

h. Memiliki tingkat energi, spontanitas dan petualangan yang luar biasa;

i. Mempunyai rasa humor yang tinggi;

j. Melihat masalah dari berbagai sudut;

k. Memiliki kemampuan untuk bermain dengan ide, konsep atau kemungkinan-kemungkinan yang dikhayalkan;

I. Kecenderungan melakukan refleksi;

$\mathrm{m}$. Cepat menunjukkan perhatian pada masalah orang dewasa (seperti tentang politik, ekonomi yang diamati dalam masyarakat).

\section{PERAN ORANG TUA, SEKOLAH DAN MASYARAKAT DALAM MENGEMBANGKAN KREATIVITAS ANAK}

\section{a. Peran Orang Tua}

Dalam membantu anak mewujudkan kreativitas mereka perlu dilatih dalam keterampilan tertentu sesuai dengan minat pribadinya dan diberi kesempatan untuk mengembangkan bakat atau talenta mereka. Orang tua perlu menciptakan iklim yang merangsang pemikiran dan keterampilan kreatif anak serta menyediakan sarana prasarana. Di samping perhatian, dorongan dan pelatihan dari lingkungan, perlu ada motivasi intrinsik pada anak. Minat anak untuk melakukan sesuatu harus tumbuh dari dalam dirinya atas keinginannya sendiri.

Keberhasilan kreatif adalah persimpangan antara keterampilan anak dalam bidang tertentu, keterampilan berpikir kreatif serta motivasi intrinsik dapat juga disebut motivasi batin (Amabile 
dalam Utami, 1999).

Kegiatan mengobrol secara rutin dalam keluarga sangat bermanfaat. cara ini menumbuhkan rasa tanggung jawab kolektif pada anak dan orang tua, merupakan bagian dari proses pengambilan keputusan bersama. Demikian juga dengan mengembangkan rasa saling memiliki (belonging) dalam kelompok keluarga, akan mendorong timbulnya rasa tanggung jawab dan pengambilan keputusan (Donnchadha, 2004).

\section{b. Peran Sekolah}

Belajar merupakan suatu proses yang komplek terjadi pada semua orang. Menurut Arief S. Sadiman dkk (2005), pertanda bahwa seseorang telah belajar adalah adanya perubahan tingkah laku dalam dirinya, menyangkut perubahan yang bersifat pengetahuan (kognitif), keterampilan (psikomotorik) maupun yang menyangkut nilai dan sikap (afektif).

Semua anak di sekolah memerlukan guru yang baik tidak hanya anak berbakat. Namun demikian untuk mengajar anak berbakat perlu guru tertentu yang mampu mengembangkan bakat kreativitas anak tersebut. Menurut McInerney and McInerney (1998), bahwa mengembangkan anak kreatif jangan terlalu membatasi/mencegah dan menakut-nakuti, hal ini sebagai upaya pengendaliannya. Jangan salah menempatkan dalam menentukan keahlian verbal. Kritik yang destruktif dan tekanan dari kelompok sebaya dalam menyesuaikan diri perlu mendapat perhatian.

Adapun ciri-ciri guru yang dibutuhkan bagi anak berbakat adalah : sikap demokratis, ramah, dan memberi perhatian perorangan, sabar, minat luas, penampilan yang menyenangkan, adil, tidak memihak, rasa humor, perilaku konsisten, memberi perhatian terhadap masalah anak, kelenturan, menggunakan penghargaan dan pujian serta 
kemahiran yang luar biasa dalam mengajar subjek tertentu.

Hasil penelitian Davis dalam Utami (1999), menunjukkan bahwa ciri-ciri profesional, seperti minat untuk belajar dan kemahiran dalam mengajar dinilai lebih penting dari pada ciri seperti penampilan dan sikap yang menyenangkan. Dalam penilaian ciri-ciri guru anak berbakat menurut para responden (siswa) diperoleh urutan sebagai berikut:

\section{Karakteristik Guru yang penting dalam pendidikan} anak berbakat:

\begin{tabular}{|c|l|c|}
\hline No. & \multicolumn{1}{|c|}{ Pilihan } & Persentase \\
\hline \hline 1. & Kompetensi dan minat untuk belajar & 98 \\
\hline 2. & Kemahiran dalam mengajar & 95 \\
\hline 3. & Adil dan tidak memihak & 93 \\
\hline 4. & Sikap kooperatif demokratis & 92 \\
\hline 5. & Fleksibilitas & 90 \\
\hline 6. & Rasa humor & 90 \\
\hline 7. & Menggunakan penghargaan dan pujian & 88 \\
\hline 8. & Minat luas & 85 \\
\hline 9. & Memberi perhatian thd masalah anak & 83 \\
\hline 10. & Penampilan dan sikap yang menarik & 79 \\
\hline
\end{tabular}

Sumber: Sisk, D.,

Creative Teaching of The Gifted, dalam Utami (1999)

\section{c. Peran Masyarakat}

Kondisi sosiokultural dapat memudahkan atau menghambat pengembangan kreatifitas anak dan pertumbuhan bakat. Masyarakat dapat mengusahakan suasana atau iklim yang baik guna menunjang pengembangan kreatifitas anak-anak mereka. 
Yang penting disini adalah bahwa seseorang merasa aman secara psikologis dan bebas untuk mengembangkan dan mengungkapkan diri dalam lingkungan di mana ia hidup.

Menurut Simonton, dalam Utami (1999), bahwa masa perkembangan anak dan remaja sampai kedewasaan cenderung lebih nyata dipengaruhi oleh kejadian-kejadian eksternal daripada masa-masa produktivitas khusus yang kebal terhadap kejadian eksternal. la menemukan tujuh perubah yang mempengaruhi perkembangan kreatif anak yaitu:

1) Pendidikan formal mempunyai pengaruh yang kuat terhadap kreativitas seorang anak selama tumbuh kembang, tetapi di luar batas tertentu dapat menghambat perkembangan kreativitas dengan memaksakan komitmen yang berlebih terhadap perspektif tradisional.

2) Adanya pencipta ulung yang dapat menjadi model peran untuk diidentifikasi sangat penting bagi pemunculan pencipta lain yang unggul, sehingga makin banyak model peran yang ada untuk identifikasi selama masa perkembangan seorang genius, makin besar peningkatan potensi kreatif.

3) Sehubugan dengan Zeitgeist, yaitu adanya pengaruh dari iklim mental pada waktu tertentu dalam sejarah, penelitian Simonton menunjukkan bahwa pemikir ulung paling banyak dipengaruhi oleh Zeitgeist yang mendominasi situasi intelektual selama masa perkembangan, yang membuat mereka khusuk bersibuk diri dengan mengembangkan gagasan-gagasan yang banyak ditampilkan.

4) Fragmentasi politis yaitu adanya berbagai negara bagian yang independen dalam satu peradaban, menimbulkan perbedaan kultural yang sangat mempengaruhi perkembangan kreativitas, karena membentuk dasar intelektual pencipta kearah keterbukaan terhadap pengalaman, perubahan, individualisme dan kesejahteraan material. 
5) Keadaan perang yang terus-menerus dapat merugikan perkembangan kreativitas anak karena tidak mendorong kualitas intelektual.

6) Gangguan sipil misalnya pemberontakan rakyat, pertentangan dan revolusi dapat mempunyai pengaruh potensial yang negatif bagi perkembangan kreativitas.

7) Dari semua pengaruh ini menurut Simonton ketidakstabilan politis paling merugikan perkembangan kreativitas karena untuk menjadi kreatif seseorang harus menghayati dunianya yang diandalkan dan dikendalikan, sehingga pribadi mempunyai prospek membuahkan sesuatu yang bermakna.

\section{BIMBINGAN DAN KONSELING BAGI ANAK BERBAKAT KREATIF}

Bimbingan sebagai proses untuk membantu individu memperoleh pengertian tentang diri sendiri dan pengarahan diri yang diperlukan untuk menyesuaian secara maksimal di sekolah, rumah dan masyarakat. Senada dengan hal tersebut bahwa tujuan konseling adalah untuk membantu semua individu menyesuaikan diri dan tumbuh di dalam lingkungan menuju perkembangan diri yang maksimal. Mathewson dalam Syamsu dan A. Juntika (2005), mencatat empat hal mengapa individu membutuhkan bimbingan dan konseling, yaitu:

a. Kebutuhan individu untuk menilai dan memahami diri;

b. Kebutuhan untuk menyesuaikan diri dengan diri sendiri dan tututan lingkungan;

c. Kebutuhan untuk memiliki orientasi atau wawasan tentang berbagai kondisi yang terjadi pada masa sekarang dan yang akan datang;

d. Kebutuhan untuk mengembangkan potensi pribadi.

Banyak contoh anak berbakat kreatif mengalami kesulitan di sekolah karena lingkungan yang ekstrem "terlalu membatasi" atau 
"terlalu permisif". Konselor perlu menemukenali anak-anak kreatif ini dan memberi sistem dukungan yang memupuk produktivitas kreatif mereka (Davis dan Rimm, dalam Utami, 1999). Guru dan konselor yang bekerja dengan anak kreatif perlu mengingat bahwa

a. Anak kreatif lebih suka belajar sendiri;

b. Anak kreatif kurang menyukai tugas-tugas rutin, tetapi lebih tertantang oleh tugas yang majemuk dan sulit;

c. Keunikan anak kreatif sering kurang dihargai;

d. Bakat kreatif anak hanya tampil dalam bidang-bidang tertentu.

Selanjutnya beberapa saran menurut Davis and Rimm dalam Utami Munandar (1999), yang perlu diberikan dalam membina anak-anak kreatif sehubungan dengan dukungan lingkungan yang mereka perlukan, adalah:

1) Fleksibilitas dalam kesempatan. Perlu diupayakan fleksibilitas dalam memberi kesempatan yang menuju ke pengarahan diri secara bertanggung jawab;

2) Contoh yang positif. Tokoh model yang baik dapat memberi gambaran yang komprehensif kepada siswa kreatif mengenai jenis keterampilan yang diperlukan agar produktif dalam bidang minat khusus mereka dan sekaligus menumbuhkan motivasi mereka. Konselor dalam hal ini dapat mempertimbangkan seorang mentor sebagai model yang sesuai dengan minat khusus anak.

3) Bimbingan dan dukungan. Anak kreatif memang memerlukan penguatan untuk prestasi mereka agar menjadi percaya diri terhadap karya kreatifnya. tetapi pujian berlebih dan tidak selektif menjadi kurang bermakna. Sebab pribadi yang kreatif menghargai nilai yang sesuai. Pujian untuk karya yang berkualitas dan kritik yang positif konstruktif mendukung pertumbuhan kemampuan kreatif dan kepercayaan diri.

4) Rasa humor. Rasa humor yang kuat dari anak berbakat kreatif sering mengakibatkan masalah disiplin dalam lingkungan tanpa humor. Humor sebagai bakat dapat disalurkan ke ungkapan 
kreatif secara lisan dan tulisan, drama dan karya seni serta dapat menjadi dasar dari kepemimpinan yang berhasil di antara teman sebaya.

5) Empati. Siswa kreatif biasanya mengenal dirinya sebagai yang berbeda. Konselor yang memahami dan memberi dukungan dapat membantu menyelamatkan siswa kreatif dari kepercayaan yang menyakitkan bahwa ada sesuatu yang "salah" pada mereka. Dengan memberikan empati, seorang konselor dapat menghindari kecenderungan siswa kreatif untuk membuktikan kepada teman sebaya bahwa mereka "sama seperti yang lain" dengan upaya-upaya tidak kreatif yang hanya membuang-buang talenta mereka.

\section{KESIMPULAN}

a. Bakat diartikan sebagai kemampuan bawaan, sebagai potensi yang masih perlu dikembangkan dan dilatih agar dapat terwujud.

b. Kreativitas adalah kemampuan untuk menciptakan suatu karya baru yang merupakan hasil dari pemikiran dan gagasan, termasuk kemampuan membuat alternatif pemecahan masalah berdasarkan data, informasi yang dikaji secara cerdik.

c. Sikap dan perilaku kreatif perlu dipupuk sejak dini, agar anak didik kelak tidak hanya menjadi konsumen pengetahuan, tetapi mampu menghasilkan pengetahuan baru, tidak hanya menjadi pencari kerja, tetapi mampu menciptakan pekerjaan baru.

d. Peran orang tua, sekolah/guru dan masyarakat dalam mengembangkan kreativitas anak sangat menentukan dan perlu dilakukan secara sinergi.

e. Mengembangkan anak kreatif jangan terlalu membatasi/ mencegah dan menakut-nakuti, jangan salah menempatkan dalam menentukan keahlian verbal. Kritik yang destruktif dan tekanan dari kelompok sebaya dalam menyesuaikan diri perlu mendapat perhatian.

f. Kreativitas anak membutuhkan dorongan dalam dirinya (motivasi intrinsik) maupun dorongan dari lingkungan (motivasi 
ekstrinsik). Dorongan internal membutuhkan kondisi yang tepat untuk diekspresikan. Kondisi lingkungan yang mendorong kreativitas anak yaitu penciptaan kondisi keamanan dan kebebasan psikologis yang memungkinkan timbulnya kreativitas yang konstruktif.

g. Ciri-ciri guru yang dibutuhkan bagi anak berbakat kreatif adalah: sikap demokratis, ramah, dan memberi perhatian perorangan, sabar, minat luas, penampilan yang menyenangkan, adil, tidak memihak, rasa humor, perilaku konsisten, memberi perhatian terhadap masalah anak, kelenturan, menggunakan penghargaan dan pujian serta kemahiran yang luar biasa dalam mengajar subjek tertentu.

h. Konselor yang bekerja dengan anak kreatif perlu mengingat bahwa:

1) Anak kreatif lebih suka belajar sendiri;

2) Anak kreatif kurang menyukai tugas-tugas rutin, tetapi lebih tertantang oleh tugas yang majemuk dan sulit;

3) Keunikan anak kreatif sering kurang dihargai;

4) Bakat kreatif anak hanya tampil dalam bidang-bidang tertentu.

\section{DAFTAR PUSTAKA}

Arief S. Sadiman dkk (2005), Media Pendidikan, Pengertian, Pengembangan dan Pemanfaatannya, Jakarta: Raja Grafindo Persada.

Donnchada, Rammon O. (2004), Anak yang Percaya Diri, Petunjuk Membentuk Kepribadian Anak, alih bahasa: A. Rahartati Bambang, Jakarta: Penerbit Buku Populer Nirmala.

McInerney, Dennis M. and McInerney, Valentina (1998), Educational Psychology: Constructing Learning, Second Edition, New York: Prentice Hall.

Syamsu Yusuf dan A. Juntika Nurihsan (2005), Landasan Bimbingan dan Konseling, Bandung: Remaja Rosdakarya.

Utami Munandar (1999), Pengembangan Kreativitas Anak Berbakat, 
Jakarta: Rineka Cipta.

(1999), Mengembangkan Bakat dan Kreativitas Anak Sekolah, Petunjuk Bagi Para Guru dan Orang Tua, Jakarta: Gramedia Widiasarana Indonesia. 